\section{ECCOMAS}

\section{Proceedia}

COMPDYN 2021

$8^{\text {th }}$ ECCOMAS Thematic Conference on Computational Methods in Structural Dynamics and Earthquake Engineering

M. Papadrakakis, M. Fragiadakis (eds.)

\title{
EFFECT OF EXTREMELY LOW TEMPERATURE ON MECHANICAL PROPERTIES OF A LARGE SIZE LRB
}

\author{
G. Ozdemir ${ }^{1}$, E. Cavdar ${ }^{1}$, and V. Karuk ${ }^{1}$ \\ ${ }^{1}$ ESQUAKE Seismic Isolator Test Laboratory, Eskisehir Technical University \\ Eskisehir, Turkey \\ e-mail: gokhan_ozdemir@eskisehir.edu.tr \\ \{esengulcavdar, volkankaruk\}@eskisehir.edu.tr
}

\begin{abstract}
The most important demand parameter for a seismically isolated structure is the maximum displacement at the isolation level. Currently, the most accurate way to estimate both the maximum isolator displacement and the isolator shear force is to perform bounding analyses. Accordingly, in bounding analyses, the lower and upper bound characteristics of isolator units are used in order to consider the change in isolator properties due variation in loading history, aging and environmental factors such as climatic conditions that the isolator is exposed during its lifetime. The objective of this study is to experimentally investigate the change in mechanical properties of a lead rubber bearing under very low ambient temperature. For this purpose, a lead rubber bearing with a total height of $361 \mathrm{~mm}$, a diameter of $1020 \mathrm{~mm}$ and a lead core diameter of $190 \mathrm{~mm}$ is subjected to displacementcontrolled loading at different ambient temperatures. The seismic isolator unit was first kept in room condition $\left(20^{\circ} \mathrm{C}\right)$ for 24 hours in ESQUAKE Seismic Isolator Test Laboratory established in Eskisehir Technical University and then tested under cyclic motion. Then, the isolator unit which was conditioned at $-30^{\circ} \mathrm{C}$ for 24 hours, was subjected to the same cyclic loading. Recorded force-displacement curves for both ambient temperatures are compared. In the loading protocol, the amount of axial load was $4500 \mathrm{kN}$ (6 MPa normal stress), the amplitude of the horizontal motion was $280 \mathrm{~mm}$ (100\% shear strain), the number of cycles was 3 and the frequency of motion was $0.1 \mathrm{~Hz}$. Based on the test results conducted for both ambient temperatures, post-yield stiffness, effective stiffness, energy dissipated per cycle and equivalent damping ratios of the isolator were calculated for each cycle and compared with each other. Results showed that mechanical properties of lead rubber bearing significantly changed under low ambient temperature when compared to those obtained at laboratory conditions. When the ambient temperature drops down to $-30^{\circ} \mathrm{C}$ from $20^{\circ} \mathrm{C}$, the amplifications in post yield stiffness and characteristic strength are $10 \%$ and $50 \%$, respectively.
\end{abstract}

Keywords: Seismic Isolation, Ambient Temperature, Cyclic Loading, Lead Rubber Bearing. 


\section{INTRODUCTION}

Seismic isolation is an earthquake resistant design strategy which is adopted to protect structures against adverse effects of ground motions. It relies on lengthening of natural period of structure by introducing systems, that possess low horizontal stiffness, between the superstructure and substructure. Accordingly, in case of a seismic excitation, rather than the seismically isolated structure, seismic isolators will undergo large deformations and dissipate energy. Among various seismic isolation systems, lead rubber bearing (LRB) is one of the most widely used seismic isolators. They are composed of alternate layers of rubber and steel plates with a lead core at the center that passes through the height of the bearing. Rubber layers are responsible for the lateral stiffness of the bearing whereas lead core provides the required lateral strength. Since it was invented by Robinson in the 1970s, LRBs have been used in several structures (bridges, hospitals, data centers etc.) around the world [1-3]. In parallel, several research has been conducted to determine performance of LRBs under the effect of different parameters [4-10]. One of these parameters is the change in ambient temperature.

Mechanical properties of LRBs, mainly post yield stiffness and characteristic strength, are related to properties of rubber and lead, respectively. Although there are numerous studies that focused on the change in rigidity of rubber at low temperatures [11-17], very few experimental data are available for modification of LRB properties at low temperatures [1820]. The LRB tested by Hasegawa et al. [18] was $250 \mathrm{~mm}$ in diameter with a lead core diameter of $38 \mathrm{~mm}$. Displacement controlled LRB tests were conducted at temperatures of 40, 20,0 and $-20^{\circ} \mathrm{C}$ for a shear strain of $100 \%$ at $0.3 \mathrm{~Hz}$. It was reported that the exposure time of the bearing to these temperatures is 5hrs. Similarly, Constantinou et al. [7] conducted tests with an LRB having rubber and lead core diameters of $381 \mathrm{~mm}$ and $70 \mathrm{~mm}$, respectively. Isolator tests were carried out at a shear strain of $58 \%$ and loading frequency was $0.35 \mathrm{~Hz}$. Constantinou et al. [7] stated that LRB was conditioned at $-26^{\circ} \mathrm{C}$ and $20^{\circ} \mathrm{C}$ for $48 \mathrm{hrs}$ prior to tests. Compared to LRBs used in experimental studies of Hasegawa et al. [18] and Constantinou et al. [7], LRB tested by Cho et al. [19] was a large size bearing with rubber and lead core diameters of $860 \mathrm{~mm}$ and $170 \mathrm{~mm}$, respectively. The total rubber thickness was 288 $\mathrm{mm}$ and tested at a shear strain of $15 \%$. Temperatures considered by Cho et al. [19] were -20 , $-10,0$ and $23^{\circ} \mathrm{C}$. It is to be mentioned that $15 \%$ shear strain is very low to be representative of seismic behavior of an LRB designed to undergo large deformations. Accordingly, variation in mechanical properties of a large size LRB exposed to low temperature was revisited by Park et al. [20]. Rubber and lead core diameters of the LRB were $800 \mathrm{~mm}$ and $180 \mathrm{~mm}$, respectively and tested at a shear strain of $100 \%$.

The objective of this study is to determine the effect of low ambient temperature on mechanical properties of a lead rubber bearing. Accordingly, first, a large-size LRB was tested at both room $\left(20^{\circ} \mathrm{C}\right)$ and low $\left(-30^{\circ} \mathrm{C}\right)$ temperatures under dynamic conditions. The tested seismic isolator is subjected to displacement-controlled loading cycles that corresponds to $100 \%$ shear strain. Test results obtained for two distinct ambient temperatures are used to construct force-displacement curves for both conditions. Variation in characteristic strength $(Q)$, post yield stiffness $\left(K_{d}\right)$, effective stiffness $\left(K_{\text {eff }}\right)$, dissipated energy per cycle $(E D C)$ and equivalent damping ratio $\left(\xi_{\text {eff }}\right)$ computed for both conditions are compared with each other. 


\section{TESTED LEAD RUBBER BEARING}

The bearing tested in this study is a large-size LRB with rubber and lead core diameters of $1020 \mathrm{~mm}$ and $190 \mathrm{~mm}$, respectively. Height of the bearing is $436 \mathrm{~mm}$ including the top and bottom plates together with the end shim at the top. It is composed of 28 layers of rubber each of which has $10 \mathrm{~mm}$ thickness with a total rubber height of $280 \mathrm{~mm}$. Geometrical properties of the tested LRB is presented in Figure 1.

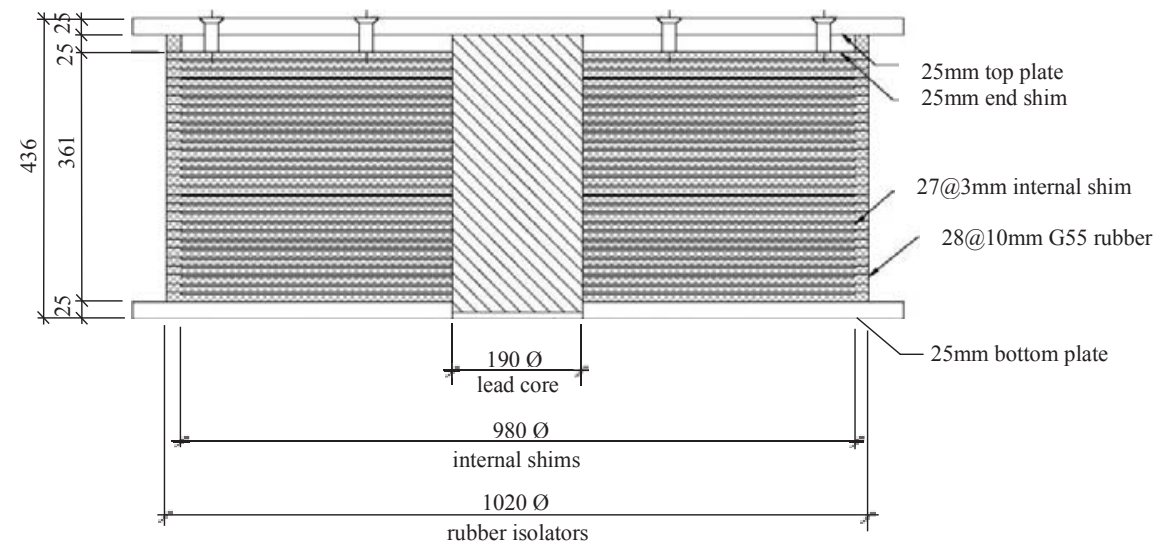

Figure 1: Section cut of test specimen.

\section{ISOLATOR TESTS AT ROOM AND LOW AIR TEMPERATURE}

In order to determine the mechanical properties of the specimen, its hysteretic response in shear was recorded under a constant compressive load. Accordingly, the LRB was subjected to three cycles of sinusoidal motion with amplitude equals to $280 \mathrm{~mm}$ that corresponds to $100 \%$ shear strain. Frequency of the motion was $0.1 \mathrm{~Hz}$ where the maximum velocity is 176 $\mathrm{mm} / \mathrm{s}$. The axial force acting on the bearing was $4500 \mathrm{kN}$ which result in $6 \mathrm{MPa}$ normal stress. The LRB was first tested at a temperature of $20^{\circ} \mathrm{C}$ after conditioning for 24 hours inside the laboratory and tested again at a temperature of $-30^{\circ} \mathrm{C}$ after conditioning for 24 hours inside the air-conditioned room (Figure 2.a). Tests were conducted at ESQUAKE Seismic Isolator Test Laboratory of Eskisehir Technical University. The test setup of ESQUAKE shown in Figure 2.b is capable of applying dynamic motions in both horizontal and vertical directions. Table 1 presents the loading capacities of ESQUAKE test setup. Horizontal forcedisplacement curves obtained from tests for $20^{\circ} \mathrm{C}$ and $-30^{\circ} \mathrm{C}$ are given in Figure 3 .

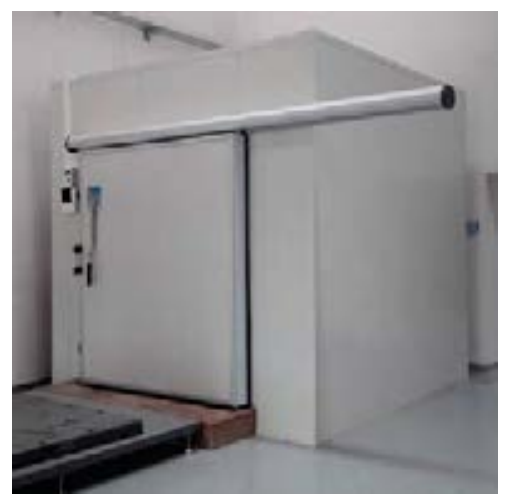

(a)

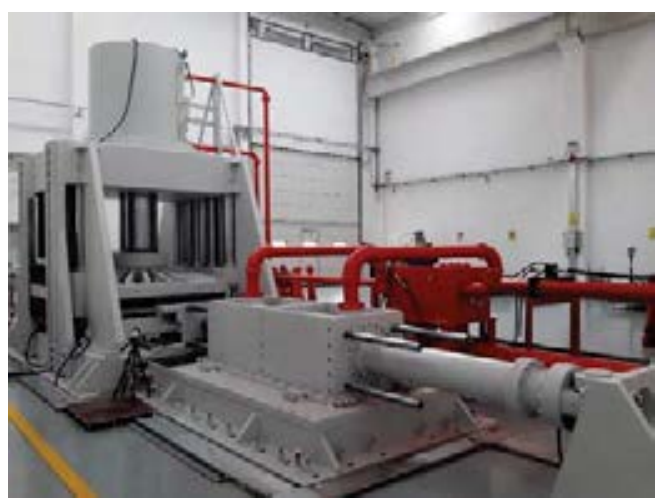

(b)

Figure 2: (a) Air-conditioned room and (b) seismic isolator test setup of ESQUAKE 


\begin{tabular}{c|c}
\hline Max. Vertical Load: & $20.000 \mathrm{kN}$ \\
\hline Max. Horizontal Load: & $2.000 \mathrm{kN}$ \\
\hline Max. Horizontal Stroke: & $\pm 600 \mathrm{~mm}$ \\
\hline Max. Velocity: & $1.000 \mathrm{~mm} / \mathrm{s}$ \\
\hline
\end{tabular}

Table 1: Properties of ESQUAKE test setup.

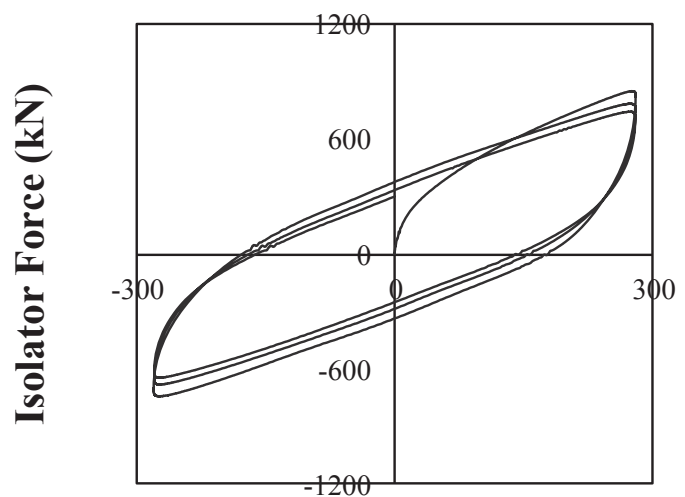

(a)

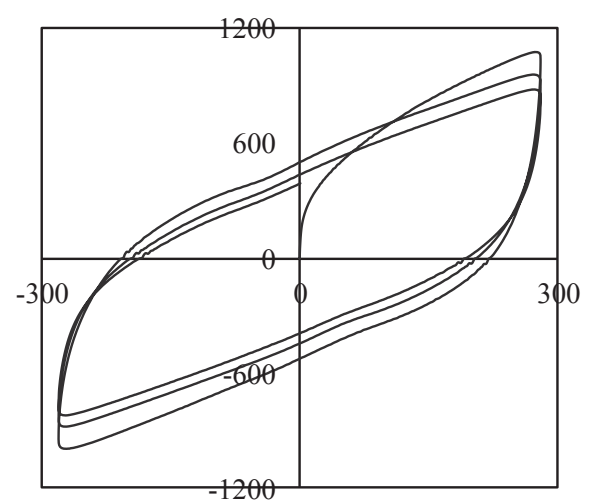

(b)

Displacement (mm)

Figure 3: Force-displacement curves of LRB tested at a) $20^{\circ} \mathrm{C}$ and b) $-30^{\circ} \mathrm{C}$.

\section{MECHANICAL PROPERTIES OF LRB}

Mechanical properties of the tested LRB such as post-yield stiffness $\left(K_{d}\right)$, characteristic strength $\left(Q_{d}\right)$, effective stiffness $\left(K_{e f f}\right)$, energy dissipation capacity (EDC) and effective damping ratio $\left(\xi_{\text {eff }}\right)$ for temperatures of $20^{\circ} \mathrm{C}$ and $-30^{\circ} \mathrm{C}$ are presented in Table 2. Data given in Table 2 are computed by means of Equations (1)-(4) and Figure 4. In Equations (1) and (2), $\mathrm{Q}_{1}{ }^{\prime}, \mathrm{Q}_{1}{ }^{\prime \prime}, \mathrm{Q}_{2}{ }^{\prime}$ and $\mathrm{Q}_{2}{ }^{\prime \prime}$ are the isolator forces at $50 \%$ of the maximum positive and negative horizontal displacements $d_{\max }$ and $d_{\min }$ as per ISO 22762-1 [21]. $\mathrm{Q}_{1}$ and $\mathrm{Q}_{2}$ of Equation (3) are the isolator forces at $d_{\max }$ and $d_{\min }$, respectively (see Figure 4).

\begin{tabular}{ccccccc}
\hline Temperature & Cycle & $\begin{array}{c}Q_{d} \\
(\mathrm{kN})\end{array}$ & $\begin{array}{c}K_{d} \\
(\mathrm{kN} / \mathrm{m})\end{array}$ & $\begin{array}{c}K_{\text {eff }} \\
(\mathrm{kN} / \mathrm{m})\end{array}$ & $\begin{array}{c}E D C \\
(\mathrm{kN} \cdot \mathrm{m})\end{array}$ & $\begin{array}{c}\xi_{\text {eff }} \\
(\%)\end{array}$ \\
\hline \multirow{3}{*}{$-30^{\circ} \mathrm{C}$} & 1 & 489 & 2020 & 3441 & 504 & 0.29 \\
& 2 & 414 & 1919 & 3100 & 433 & 0.28 \\
& 3 & 372 & 1864 & 2913 & 382 & 0.26 \\
$20^{\circ} \mathrm{C}$ & 1 & 324 & 1833 & 2706 & 335 & 0.25 \\
& 2 & 286 & 1796 & 2510 & 297 & 0.24 \\
& 3 & 260 & 1766 & 2392 & 264 & 0.22 \\
\hline
\end{tabular}

Table 2: Mechanical properties of LRB at $20^{\circ} \mathrm{C}$ and $-30^{\circ} \mathrm{C}$

In order to better understanding of change in mechanical properties of LRB isolator at low temperature, Figure 5 is depicted. In this figure amount of variation in isolator properties with respect to the room temperature is presented for all considered features. Accordingly, comparison of test results obtained for temperatures of $20^{\circ} \mathrm{C}$ and $-30^{\circ} \mathrm{C}$ reveals the following conclusions. Characteristic strength (force intercept at zero displacement) $Q_{d}$ of the tested LRB increases when the temperature drops down to $-30^{\circ} \mathrm{C}$. The amount of amplification in $Q_{d}$ is $50 \%$ for the first cycle whereas it is $45 \%$ and $43 \%$ for the second and third cycles, 
respectively. Similarly, post-yield stiffness $K_{d}$ of the LRB increases as the temperature decreases. However, the amount of variations in $K_{d}$, which are $10 \%, 7 \%$ and $6 \%$ for first, second and third cycles, are relatively small compared to those computed for $Q_{d}$. Based on the data presented in Table 2, the amount of change in effective stiffness $K_{\text {eff }}$ due to temperature decrease is $27 \%$ for the first cycle and reduced to $24 \%$ and $22 \%$ for the second and third cycles, respectively. According to Table 2, energy dissipation capacity EDC, defined as the area under force-displacement curve at each cycle, increases as the temperature decreases. Amplification in EDC at first, second and third cycles are computed as 50\%, 46\% and 44\% in the same order. In parallel, reducing the temperature from $20^{\circ} \mathrm{C}$ to $-30^{\circ} \mathrm{C}$ contributes to an increase in effective damping ratio $\xi_{\text {eff }}$ equal to $17 \%$ for the first cycle. The amplifications are $19 \%$ and $18 \%$ for the second and third cycles, respectively. Considering the test results, it is evident that amount of variation in mechanical properties of LRB is not constant at all loading cycles and the trend is to decrease with increasing number of cycles.

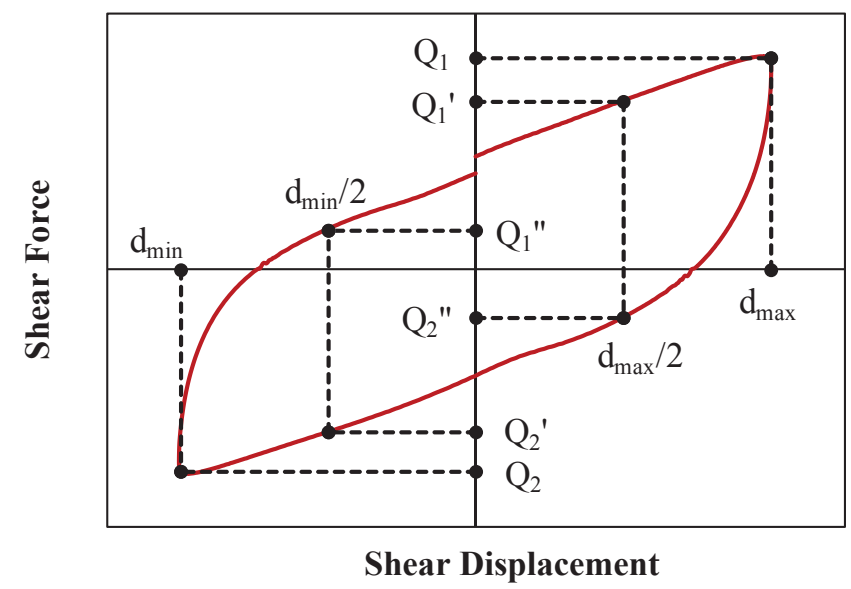

Figure 4 - Force-displacement definitions for LRBs.

$$
\begin{gathered}
\mathrm{Q}_{d}=\left[\frac{Q_{1}^{\prime \prime} d_{\text {max }} / 2-Q_{1}^{\prime} d_{\text {min }} / 2}{\left(d_{\text {max }}-d_{\text {min }}\right) / 2}-\frac{Q_{2}^{\prime} d_{\text {max }} / 2-Q_{2}^{\prime \prime} d_{\text {min }} / 2}{\left(d_{\text {max }}-d_{\text {min }}\right) / 2}\right] / 2 \\
K_{d}=\left[\frac{Q_{1}^{\prime}-Q_{1}^{\prime \prime}}{\left(d_{\text {max }}-d_{\text {min }}\right) / 2}+\frac{Q_{2}^{\prime \prime}-Q_{2}^{\prime}}{\left(d_{\text {max }}-d_{\text {min }}\right) / 2}\right] / 2 \\
K_{e f f}=\left[\frac{Q_{1}-Q_{2}}{d_{\text {max }}-d_{\text {min }}}\right] \\
\xi=\left[\frac{E D C}{\pi\left(F_{\text {max }} D_{\text {max }}+F_{\text {min }} D_{\text {min }}\right)}\right]
\end{gathered}
$$




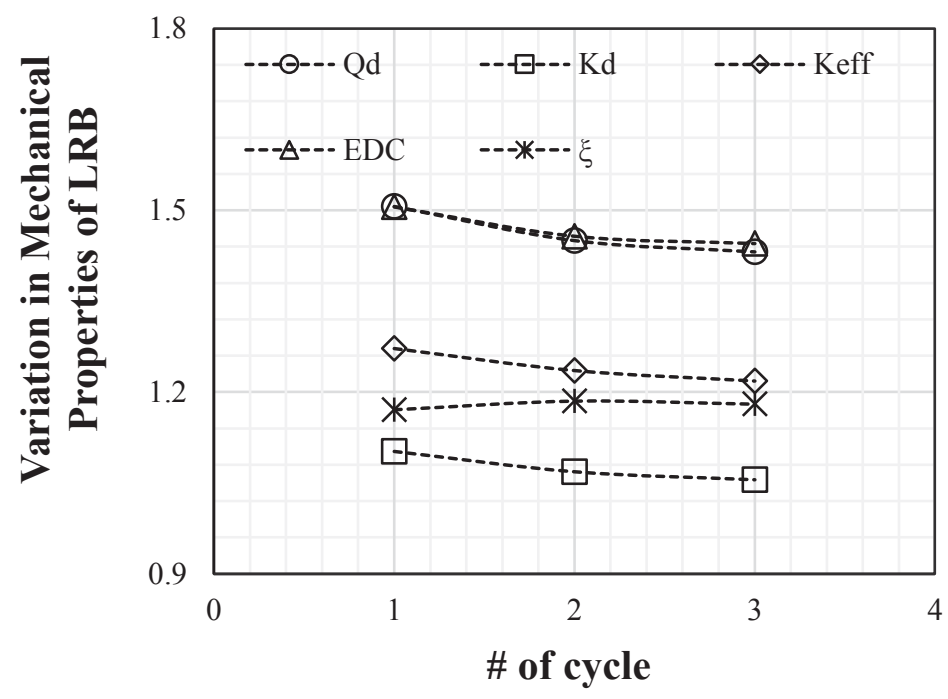

Figure 5: Amount of variation in mechanical properties of LRB isolator per cycle with respect to room temperature.

\section{CONCLUSIONS}

This study quantifies the variation in mechanical properties of an LRB isolator under the effect of very low ambient temperatures. For this purpose, an experimental investigation was performed at $20^{\circ} \mathrm{C}$ to $-30^{\circ} \mathrm{C}$. Recorded force-displacement curves for both considered temperatures are compared. Results showed that characteristic strength and post-yield stiffness of bilinear force-displacement curve of the tested LRB increases when the temperature drops from $20^{\circ} \mathrm{C}$ to $-30^{\circ} \mathrm{C}$. The amplifications in strength and stiffness are observed to be in the order of $50 \%$ and $10 \%$, respectively. As the number of cycles increases, these values decrease gradually.

\section{REFERENCES}

[1] R.I. Skinner, W.H. Robinson, G.H. McVerry, An Introduction to Seismic Isolation. Chichester: John Wiley \& Sons, 1993.

[2] F. Naeim, J. Kelly, Design of Seismic Isolated Structures: From Theory to Practice. New York: John Wiley \& Sons, 1999.

[3] M.C. Kunde, R.S. Jangid, Seismic Behavior of Isolated Bridges: A-state-of-the-art review, Electronic Journal of Structural Engineering, 3, 140-170, 2003.

[4] W.H. Robinson, Lead Rubber Hysteretic Bearings Suitable for Protecting Structures During Earthquake, Earthquake Engineering and Structural Dynamics, 10(4), 593-604, 1982.

[5] S. Nagarajaiah, X. Sun, Response of Base Isolated USC Hospital Building in Northridge Earthquake, Journal of Structural Engineering (ASCE), 126(10), 1177-1186, 2000 .

[6] C.W. Roeder, Proposed Design Method for Thermal Bridge Movements, Journal of Bridge Engineering, 8(1), 12-19, 2003. 
[7] M.C. Constantinou, A.S. Whittaker, Y. Kalpakidis, D.M. Fenz, G.P. Warn, Performance of Seismic Isolation Hardware Under Service and Seismic Loading, Technical report, NY: MCEER=07-2012, Buffalo, 2007.

[8] G. Benzoni, C. Casarotti, Effects of Vertical Load, Strain Rate and Cycling on The Response of Lead-Rubber Seismic Isolators, Journal of Earthquake Engineering, 13(3), 293-312, 2009.

[9] H. Erdoğdu, E. Çavdar, G. Özdemir, Türk Deprem Yönetmelikleri (DBYBHY ve TBDY) Spektrum Tanımlarının Deprem Yalıtım Sistemi Tasarımı Özelinde Karşılaştırılması, Teknik Dergi, 32(5), 2021.

[10] S. Pinarbasi, U. Akyuz, Sismik İzolasyon ve Elastomerik Yastik Deneyleri. IMO Teknik Dergi, 237, 3581-3598, 2005.

[11] C.W. Roeder, J.F. Stanto, A.W. Taylor, Performance of Elastomeric Bearings (No. 298). Washington, DC: National Cooperative Highway Research Program, Transportation Research Board, 1987.

[12] D.F. Ritchie, Neoprene Bridge Bearing Pads, Gaskets and Seals. Rubber World, Lippincott \& Petto Inc. 200(2), 27-31, 1989.

[13] R. Eyre, A. Stevenson, Performance of Elastomeric Bridge Bearings at Low Temperatures, Proceedings 3rd World Congress on Joint Sealing and Bearing Systems for Concrete Structures, 736-762. Toronto, Canada, 1991.

[14] A. Yakut, J.A. Yura, Evaluation of Low-Temperature Test Methods for Elastomeric Bridge Bearings, Journal of Bridge Engineering, 7(1), 50-56, 2002(a).

[15] A. Yakut, J.A. Yura, Parameters Influencing Performance of Elastomeric Bearings at Low Temperatures, Journal of Structural Engineering, 128(8), 986-994., 2002(b).

[16] K.N.G. Fuller, J. Gough, A.G. Thomas, The Effect of Low-Temperature Crystallization on The Mechanical Behavior of Rubber, Journal of Polymer Science: Part B: Polymer Physics, 42(11), 2181-2190, 2004.

[17] D. Cardone, G. Gesualdi, D. Nigro, Effects of Air Temperature on The Cyclic Behavior of Elastomeric Seismic Isolators, Bulletin of Earthquake Engineering, 9(4), 1227-55, 2011 .

[18] O. Hasegawa, I. Shimoda, M. Ikenaga, Characteristic of Lead Rubber Bearing by Temperature. Summaries of Technical Papers of Annual Meeting Architectural Institute of Japan, B-2, Structures II, Structural Dynamics Nuclear Power Plants, Architectural Institute of Japan, pp: 511-512, 1997.

[19] C.B. Cho, I.J. Kwahk, Y.J. Kim, An Experimental Study for The Shear Property and The Temperature Dependency of Seismic Isolation Bearings, Journal of the Earthquake Engineering Society of Korea, 12(1), 67-77, 2008.

[20] J.Y. Park, K.S. Jang, H.P. Lee, Y.H. Lee, H. Kim, Experimental Study on The Temperature Dependency of Full-Scale Low Hardness Lead Rubber Bearing, Journal of Computational Structural Engineering, 25(6), 533-540, 2012.

[21] ISO (International Organization for Standardization). ISO 22762-1:2005: Elastomeric seismic-protection isolators - Part 1: Test methods, 2005. 